\title{
Natural feed additives for broiler chickens
}

\author{
F.M.F. Hayajneh" \\ The Jordan University, Faculty of Agriculture, Department of Animal Production, Amman 11942, Jordan
}

(Received 4 July 2018; Accepted 18 April 2019; First published online 16 October 2019)

\begin{abstract}
Copyright resides with the authors in terms of the Creative Commons Attribution 4.0 South African License.
See: http://creativecommons.org/licenses/by/4.0/za

Condition of use: The user may copy, distribute, transmit and adapt the work, but must recognize the authors and the South African Journal of Animal Science.
\end{abstract}

\begin{abstract}
The study aims to evaluate the effects of ginger root powder and apple cider vinegar as natural feed additives on growth performance, meat quality, antimicrobial activity, and blood parameters of broiler chicken. A total of 450 one-day-old unsexed broiler chicks (Ross) were obtained from commercial hatchery and randomly distributed into three groups. Each group contained 3 replicates of 50 chicks. The 3 groups were randomly allocated to 3 treatments, where they were offered apple cider vinegar, $T_{v}$, ginger group, $T_{g}$, and control group, $T_{c}$. All the birds were offered a starter diet first 21 days filled by a grower diet from $22^{\text {nd }}$ to $35^{\text {th }}$ day and thereafter on a finisher diet up to day 35 . There was no significant difference in thawing breast weight, muscle weight, water holding capacity, and colour of the broiler chickens supplemented with ginger root and apple cider vinegar. The bacterial colonies obtained from heart, lungs, and air sacs showed a significant difference between the bacterial colonies of lungs and heart and between colonies of lungs and liver. The final body weight between the three treatments was not affected by the natural feed additive supplementation. However, there was no significant impact of ginger root and apple cider vinegar supplementation on broiler serum total protein, total cholesterol, triglyceride (Tri), ALT, and AST levels. The results concluded that herbal natural feed additives have negative impact on growth performance, meat quality, antimicrobial activity, and blood parameters of broiler chickens.
\end{abstract}

Keywords: Antimicrobial activity, Growth performance, Meat Quality

\#Corresponding author: firashope@gmail.com

\section{Introduction}

Antimicrobial compounds are commonly added to poultry diets for growth promotion and disease control at lower therapeutic doses on the basis of the observations made since 1946 (Demir et al., 2005; Kim et al., 2008; Elagib et al., 2015). Misuse of antibiotic drugs can cause drug resistance bacteria and antibiotic residue in animal products (Costa et al., 2007); therefore, natural antimicrobial products have been considered as indispensable resources (Ferrini et al., 2008). It has been shown that the use of antibiotic growth promoters among the poultry feed have been banned since 2006, although they play a beneficial role in growth performance and disease prevention among the broiler chickens by developing resistance in bacteria and presence of drug residues in meat (Gilani et al., 2018). The feed grade antibiotic growth promoters have been banned due to cross-resistance and the risk of possible drugs multiple resistances in human pathogenic bacteria. Natural products of plant origin, like spices, herbs, and many plant extracts can be used as alternative to antibiotics for growth promotion to improve broiler performance (Hernandez et al., 2004). Herbal extraction is considered as a useful growth promoter of similar effects, which is similar to antibiotics, when used in broiler feeds (Elamin et al., 2015). The earliest known use of vinegar was more than 10,000 years ago. This information relates to the present study as vinegar is medicinally used for managing wounds. Moreover, the potential health benefits of vinegar varieties have led the researchers to further consider this food product that is being used since long.

Rhizome or root part of ginger (genus Zingiber) is extensively employed in medicine for the management of different diseased conditions; like nausea, vomiting, motion sickness, gastrointestinal ulcers, diabetes, fever, arterial tension, rheumatoid arthritis, dry mouth/ xerostomia, cancer, migraine headache, sore throat, and minor respiratory ailments. Zingiber officinale Roscoe, commonly known as Ginger, belongs to the Zingiberaceae family (Riaz et al., 2015). The fat content of broiler carcasses is likely to increases by 
using drugs as feed additives (Aletor et al., 2000). Thus, the recent nutritional plans for feed cost reduction have resulted in fatty broiler carcasses (Ademola et al., 2009). The nutritional strategies aim to reduce the feed costs that leads to the production of fatty broiler carcasses (Ademola et al., 2009). The natural herbs, including ginger power and apple cider vinegar, are known to possess lipid reducing effects and promote growth, similar to antibiotics, when used in the feeds of broiler chicken (Elagib et al., 2013). The natural feed additives are capable of enhancing poultry production and broiler performance through improved nutrient digestion and absorption by reducing enteric pathogenic microbial loads. Good health status is likely to be maintained among the broiler chickens that is contributed through the buffering capacity of diets. Moreover, the buffering capacity is likely to be enhanced through the supplementation of organic acids (Papatsiros et al., 2012).

Ginger has gained prominence due to its wide range of properties with the basic aim of improving the nutritive value of animal product (meat, milk or egg). The ginger protease could be useful in the tenderization process and improving the quality of meat (Naveena \& Mendiratta, 2001). Apple cider vinegar is broken down into alcohol and later into vinegar by the yeast and bacteria after it is consumed by the broiler chicken. On maturation, vinegar turns into cloudy dark substance. Acetic acid is the main ingredient of apple cider vinegar. On the other hand, the efficacy of ginger powder makes it a potent compound for treating wide range of diseases. However, rapid removal and inactivity of metabolic compound decrease the availability of the agent. Unfortunately, limited information is available in the literature, concerning the study of using ginger powder and apple cider vinegar as a supplementation to the diet and their effects on broiler meat quality parameters. Therefore, the study aims to investigate the effects of supplementation in ginger root and apple cider vinegar on growth performance, meat quality, and blood parameters of broiler chicken.

\section{Materials and Methods}

A total of 450 one-day old hatched Ross straight-run broilers were obtained from a commercial hatchery. The samples were randomly alienated into three treatment groups with three replicates for a 42 day feeding trial. A control (Tc) group had normal diet throughout the trial period that consist of corn and soybean meal to provide energy and protein. It contained coccidiostat and antifungal $(0.1 \mathrm{~g} / \mathrm{kg})$ and an antibiotic growth factor with $1 \mathrm{~g}$ Flaovmycin/kg diet. The second group (TV) of birds received apple cider in drinking water as follows: 1 - 2 weeks: $1 \%$ solution of apple cider vinegar, 3 - 4 weeks: $2 \%$ solution of apple cider vinegar, and 5 - 7 weeks: 3\% solution of apple cider vinegar. The third group of birds (Tg) received ginger powder added to their diet as follows: 1 - 2 weeks: $0.25 \%$ of ginger powder, $3-4$ weeks: $0.50 \%$ of ginger powder, and 5 - 6 weeks: $0.75 \%$ of ginger powder (Table 1 ).

The feeder size was kept constant as it refers to the approximate weight of chicken feed which each feeder can hold. Humidity, lightning, and ventilation of the place was also maintained for the chickens to obtain accurate results. At the end of 42 days trial, 40 birds from each treatment were randomly selected, weighed, and fasted to 10 hours prior slaughter. Slaughtered birds were scalded, and the feathers were mechanically plucked in rotary drum picker and eviscerated. Feet, shanks, neck, and head were removed; and carcasses were immediately weighed to obtain post slaughter hot carcasses weight without goblets. Carcasses were refrigerated for 24 hours at $2-3^{\circ} \mathrm{C}$ and weighed again to obtain cold carcass weight as the percentage of live-weight to determine dressing percentage. The carcasses were then dissected into different commercial parts (breast, thighs and wings). Each part was weighed separately, put in sealed plastic bags, and stored at $-20{ }^{\circ} \mathrm{C}$ for further chemical analysis. Cuts were related to the carcass weight and expressed in percentage. Meat samples were minced to make homogenous paste by passing them through a grinder fitted with a fine screen three time.

The $\mathrm{pH}$ values were determined by using iodo-acetate method described by Jeacocke (1977) and Sams and Janky (1986). According to this method, $\mathrm{pH}$ was recorded after $1-1.5 \mathrm{~g}$ of raw muscles were put into plastic test tube containing $10 \mathrm{ml}$ of neutralized $5 \mathrm{mM}$, using the $\mathrm{pH}$ meter ( $\mathrm{pH}$ spear, model 35634-40, Eurotech Instruments, Malaysia). The $\mathrm{pH}$ was measured at three points on the cranial area of pectoral superficial muscle; i.e. Major Pectoralis, at about $5 \mathrm{~cm}$ from the sternum line (Aperture U 59730-30, ColeParameter).

Blood collection was carried out before induction of coccidiosis at age of 2 weeks, using direct heart puncture. Coccidiosis is a common parasitic disease among the broiler chickens that causes infection in a specific region of the intestine. The induction of coccidiosis assists in the evaluation of haematological data that might be necessary to give a higher challenge dose and the blood was collected on the 42nd day. Sterile gauge 19 needles and syringes in tubes containing Ethylene Diamineate Acetic Acid (EDTA) were used to collect $3.5 \mathrm{ml}$ of blood from three birds per treatment that were selected randomly. The biochemical blood analysis including triglycerides, Alanine Aminotransferase (ALT), Aspartate Aminotransferase (AST), total protein, and total cholesterol was conducted through automated screening. Under testing, each analyte was processed through spectrophotometer under regulated temperature. 
Table 1 The composition ( $\mathrm{g} \mathrm{kg}-1)$ of the basal diets

\begin{tabular}{|c|c|c|c|}
\hline Ingredients & $\begin{array}{l}\text { Starter diet } \\
(0-21 d)\end{array}$ & $\begin{array}{c}\text { Grower diet } \\
(22-35 d)\end{array}$ & $\begin{array}{l}\text { Finisher diet } \\
(36-49 d)\end{array}$ \\
\hline Corn & 58.5 & 36.3 & 67.05 \\
\hline Soybean meal (48\% CP) & 35.65 & 31 & 26 \\
\hline Palm oil & 1.84 & 1.79 & 3 \\
\hline Limestone (ground) & 1 & 0.96 & 1.68 \\
\hline Dicalcium phosphate & 0.2 & 0.2 & 1.02 \\
\hline $\mathrm{NaCl}$ & 0.11 & 0.12 & 0.42 \\
\hline DL-methionine (98\%) & 0.10 & 0.1 & 0.2 \\
\hline L-Lysine-HCL (98.5\%) & 0.10 & 0.1 & 0.13 \\
\hline Coccidiostat (Amprolium 200) & 0.10 & 0.1 & -- \\
\hline Vitamin-mineral premix1 & 0.1 & 0.1 & 0.1 \\
\hline Choline chloride & 0.1 & 0.1 & 0.1 \\
\hline Antioxidant (dried Echinacea purpurea) & 0.1 & 0.1 & 0.1 \\
\hline Antifungal (peppermint oil) & 0.1 & 0.1 & 0.1 \\
\hline \multicolumn{4}{|l|}{ Calculated nutrient composition } \\
\hline ME, kcal/kg feed & 3 & 3.075 & 3.15 \\
\hline Protein & 22 & 20 & 18 \\
\hline TSSA (\%) & 0.9 & 0.86 & 0.81 \\
\hline Methionine (\%) & 0.54 & 0.51 & 0.5 \\
\hline Lysine (\%) & 1.31 & 1.20 & 1.07 \\
\hline Therionine (\%) & 0.84 & 0.76 & 0.68 \\
\hline Tryptophan (\%) & 0.29 & 0.27 & 0.23 \\
\hline $\mathrm{Ca}(\%)$ & 1.03 & 0.98 & 0.95 \\
\hline $\mathrm{P}$, nonphytate (\%) & 0.45 & 0.42 & 0.4 \\
\hline $\mathrm{Na}(\%)$ & 0.18 & 0.18 & 0.18 \\
\hline
\end{tabular}

Provided per kilogram of diet: vitamin A, 12000 IU; vitamin D3, 1500 IU; vitamin E, 50 mg; vitamin K3, 5 mg; vitamin B1, $3 \mathrm{mg}$; vitamin B2, $6 \mathrm{mg}$; niacin, $25 \mathrm{mg}$; calcium-D-pantothenate, $12 \mathrm{mg}$; vitamin B6, $5 \mathrm{mg}$; vitamin B12, $0.03 \mathrm{mg}$; folic acid, $1 \mathrm{mg}$; D-biotin, $0.05 \mathrm{mg}$; apo-carotenoic acid ester, $2.5 \mathrm{mg}$; colin chloride, $400 \mathrm{mg}$; Mn, 80 mg; Fe, 60 mg; Zn, 60 mg; Cu, 5 mg; Co, 0.20 mg; I, 1 mg; Se, 0.15 mg.

Samples (swaps) were obtained from liver, lungs, and kidneys using a sterile swap. The samples were then inoculated on blood and MacConkey agar. No growth was found on MacConkey agar, which indicated that the colonies were gram positive. The growth on blood agar was purified and tested using API kit, which showed that the colonies were Staphylococcus gallinarum and Escherichia coli.

Data was analysed using SPSS statistical software (Ver.17.0 for windows, SPSS Inc., Chicago, IL, USA). The F-test indicated significant $(P<0.05)$ differences between treatments and the means were separated by using Duncan's Multiple Range Test (DUNCAN, 1955). Meat quality data was analysed using SAS program. Friedman's test was used to compare between the colonies obtained from liver, lung, and air sacs, which indicated significant differences $(P=0.002)$. Wilkinson test was used for the bacterial colonies obtained from heart, lungs, and air sacs, which showed a significant difference between the bacterial colonies of lungs and heart $(P=0.008)$ and between colonies of lungs and liver $(P=0.002)$.

\section{Results}

The effects of dietary ginger powder and apple cider vinegar supplementation on broiler feed intake, total body weight gain, and final body weight have been presented in table 2 . The results showed that natural 
feed additive supplementation did not affect the final body weight between the three treatments $(P>0.05)$. There were no significant differences in total feed intake, total body weight gain, and feed conversion ratio among all dietary treatments.

Table 2 Effects of antibiotic growth promoter against natural feed additives (apple cider vinegar and ginger powder) in broiler diets on body weight gain, feed intake, and feed efficiency per kg of weight gain

\begin{tabular}{|c|c|c|c|c|}
\hline \multirow{2}{*}{ Variable (Initial body weight .g) } & \multicolumn{3}{|c|}{ Treatments } & \multirow{2}{*}{$\begin{array}{c}\text { SEM } \\
(0.441)\end{array}$} \\
\hline & $\mathrm{T}_{\mathrm{C}}(49)$ & $\mathrm{T}_{\vee}(49)$ & $\mathrm{T}_{\mathrm{G}}(49)$ & \\
\hline \multicolumn{5}{|c|}{ Body weight gain. G } \\
\hline 0 to $14 \mathrm{~d}$ & $91^{*}$ & $80^{*}$ & $80^{*}$ & 3.98 \\
\hline 14 to $35 d$ & 900 & 950 & 720 & 12.3 \\
\hline 35 to $42 \mathrm{~d}$ & 390 & 320 & 285 & 6.86 \\
\hline 0 to $42 \mathrm{~d}$ & 1381 & 1350 & 1085 & 21 \\
\hline \multicolumn{5}{|c|}{ Feed intake. G } \\
\hline 0 to $14 \mathrm{~d}$ & $215^{\star}$ & $198.6^{\star}$ & $283.87^{*}$ & 3.65 \\
\hline 14 to $35 \mathrm{~d}$ & 590 & 589.9 & 671.1 & 23.2 \\
\hline 35 to $42 \mathrm{~d}$ & 580 & 590 & 623 & 11.3 \\
\hline 0 to $42 \mathrm{~d}$ & 1385 & 1379 & 1578 & 36.2 \\
\hline \multicolumn{5}{|c|}{ Feed conversion ratio } \\
\hline 0 to $14 \mathrm{~d}$ & 2.36 & 2.88 & 3.54 & 0.0124 \\
\hline 14 to $35 d$ & 0.66 & 0.62 & 0.93 & 0.012 \\
\hline 35 to $42 \mathrm{~d}$ & 1.49 & 1.84 & 2.19 & 0.045 \\
\hline 0 to $42 \mathrm{~d}$ & 1 & 1.02 & 1.45 & 0.002 \\
\hline
\end{tabular}

\footnotetext{
*Means within the same row with no common superscript differ significantly $(P<0.05)$ on the basis of the treatment groups design; Tv: Commercial feed supplemented with apple cider vinegar; Tg; commercial feed supplemented with ginger root powder; Tc; Commercial feed supplemented with Antibiotic Growth Promoter (1 g Flavomycin kg-1 diet).
}

The effects of ginger root and apple cider vinegar supplementation on broiler bird's total protein, total cholesterol, triglyceride (Tri), ALT, and AST levels sampled at 42 days have been presented in table 3 . There were no significant effects of ginger root and apple cider vinegar supplementation on broiler serum total protein, total cholesterol, triglyceride (Tri), ALT, and AST levels.

Table 3 Influence of ginger root and apple cider vinegar on total protein, total cholesterol, triglyceride (Tri), ALT, and AST of broiler blood sampled at 42 days

\begin{tabular}{lccc}
\hline Variable & Tc & $T_{V}$ & $T_{G}$ \\
\hline Total protein $\left(\mathrm{g} \mathrm{dl}^{-1}\right)$ & 3.07 & 2.35 & 2.33 \\
Total protein $\left(\mathrm{g} \mathrm{dl}^{-1}\right)$ & 1.45 & 1.4 & 1.25 \\
Total cholesterol $\left(\mathrm{g} \mathrm{dl-}^{-1}\right)$ & 121 & 105 & 97.6 \\
Triglyceride $\left(\mathrm{mg} \mathrm{dl}^{-1}\right)$ & 46.3 & 24.9 & 38.3 \\
AST $\left(\mathrm{U} \mathrm{I}^{-1}\right)$ & 280 & 269 & 277 \\
ALT $\left(\mathrm{Ul}^{-1}\right)$ & 166 & 196 & 1.87 \\
\hline
\end{tabular}

\footnotetext{
${ }^{1}$ Values represent the average of three broilers in each group at $42 \mathrm{~d}$ of age.

The effects of ginger root and apple cider vinegar supplementation on thawing breast weight, muscle weight, $\mathrm{pH}$, cooking loss percentage, and shear force values are shown in Table 4. Thawing breast weight,
} 
muscle weight, water holding capacity, and colour of the birds supplemented with ginger root and apple cider vinegar had no significant difference, when compared to the control $(P>0.05)$. There were significant differences in $\mathrm{pH}$, shear force, and cooking loss when compared to the control $(P>0.05)$.

Table 4 Least-square means for broiler thawing breast weight, muscle weight, $\mathrm{pH}$, cooking loss $(\mathrm{CL})$, water holding capacity (WHC), and shear force (SF) as affected by fed diets supplemented with ginger root and apple cider vinegar

\begin{tabular}{lcccc}
\hline & $T_{C}$ & $T_{G}$ & $T_{V}$ & $P$-value \\
\hline $\mathrm{pH}$ & $5.956^{\mathrm{a}}$ & $5.916^{\mathrm{b}}$ & $5.918^{\mathrm{b}}$ & 0.026 \\
Cooking loss, \% & $16.19^{\mathrm{a}}$ & $24.08^{\mathrm{b}}$ & $22.57^{\mathrm{b}}$ & 0.006 \\
WHC, \% & 29.20 & 27.65 & 28.63 & 0.585 \\
Shear Force, kg/cm2 & $2.81^{\mathrm{a}}$ & $1.41^{\mathrm{b}}$ & $1.57^{\mathrm{b}}$ & $<0.0001$ \\
Colour coordinates & & & & \\
$\mathrm{L}$ & 39.44 & 39.51 & 38.15 & 0.564 \\
$\mathrm{~A}$ & 2.02 & 2.32 & 1.78 & 0.440 \\
B & 19.44 & 19.13 & 18.95 & 0.543 \\
Breast weight, g & 233.40 & 258.20 & 264.00 & 0.380 \\
Muscle weight, g & 174.80 & 193.60 & 171.00 & 0.577 \\
\hline
\end{tabular}

\section{Discussion}

The consumption of diet supplemented with du-sacch by broilers from group Tc was significantly decreased during the first 14 days of age $(P<0.05)$. Du-sacch is $100 \%$ natural complementary feed especially developed for the animals. This feed is rich in oligosaccharides that is ideal substrate for the lactobacilli's. The differences in feed intake of broilers given supplemented diets with antibiotic growth promoter and five natural feed additives were not significant from 14 to 35,35 to 42, and 0 to 42 days of age. These results were consistent with the studies conducted by Gebert et al. (1999), and Tucker (2002), who reported that the dietary herbal growth promoter had no significant effects on feed intake of broilers. However, this is not supported by Cross et al. (2007), who showed that the oregano supplementation to broiler diets significantly decreased the feed intake.

In the present study, the feed efficiency was not significantly affected by the treatments from 0 to 14 , 14 to 35,35 to 42 , and 0 to 42 days of age. This observation was supported by Konjufca et al., (1997), Gebert et al. (1999), and Cross et al. (2007). The numerical increase in the performance of broiler chickens occurs due to stimulation of pancreatic secretions; however, this approach did not work in the present study. It was expected that stimulation of pancreatic secretions would increase the activity of digestive enzyme activity and the antimicrobial properties of bio-active components found in these herbs. The presence of herbs in feeding diet has positive impact on the balance of microbial population within the gut (Demir et al., 2005). Feeding broilers with diet containing these herbs has positive impact on balancing of gut microbial populations.

There was no significant difference observed for total protein, albumin, total cholesterol, triglyceride, AST, and ALT levels among the dietary treatments. The results have also shown that the plasma cholesterol level was numerically higher among the broilers consuming the diet supplemented with ginger powder, as compared to the control. Feeding ginger supplements with short feeding period and relatively low doses have been implicated in the failure to reduce plasma cholesterol level. Similar results were proposed by Bordia (1981), who reported an increase in serum cholesterol followed by a subsequent reduction in a 10-month ginger feeding study, in which $0.25 \mathrm{mg} \mathrm{kg}-1$ of ginger was consumed. However, Konjufca et al. (1997) reported that feeding dietary ginger powder for 21 days significantly reduced the plasma cholesterol level in broilers. Unfortunately, only limited information is available on the effects of herbs as feed additives on the blood parameters of broilers.

A similar study investigated the impact of feeding ginger powder for enhancing the performance of broiler chicken (Fakhim et al., 2013). However, the results came out to be contrary to the findings of the 
present study as ginger powder increased body weight of the broiler chicken with 1.0 percent ginger powder in feed. The results of present study were consistent with Zomrawi et al. (2012) as it showed no significant difference in the feed intake among the control and experiment group of broiler chickens. Other studies conducted by Ramiah et al. (2014) and Zhang et al. (2009) demonstrated that there is increase in the feed intake among broiler chickens because of the synergistic impact of combination of probiotic and ginger powder. This was also supported by Karangiya et al. (2016) as the broiler chickens supplemented with ginger were observed to utilize more feed as compared to the ones, who were not provided with ginger powder.

Vinegar is a sour liquid, comprised mainly of acetic acid, typically $4-18 \%$ acetic acid by mass (Nascimento et al., 2003). The amount of acetic acid used in vinegar on a worldwide scale is not large, but it is the oldest and best-known application. Vinegar has antimicrobial properties, which make it useful for a number of applications. It is used for cleaning and treating nail fungus, head lice, warts, and ear infections (Budak et al., 2014). Thawing breast weight, muscle weight, water holding capacity, and colour of the birds supplemented with ginger root and apple cider vinegar had no significant differences, when compared to the control $(P>0.05)$. This outcome was contrary to Choi et al. (2010) who reported that there is a significant difference in $\mathrm{pH}$, shear force, and cooking loss when compared to the control $(P>0.05)$. Choi et al. (2010) studied the effects of supplemented $(0,1,3$, and $5 \%)$ ginger powder to the broiler diet and found that the $\mathrm{pH}$ values decreased with increasing levels of dietary ginger powder. There were no significant differences among all treatments in water holding capacity (WHC) and shear force in thigh muscles $(P>0.05)$.

Similar to the present study, another study was performed on female broiler chickens to examine the impact of herbal natural feed additives on the growth of broiler chickens (Raphael et al., 2017). This study tested the effects of oregano, du-sacch, quiponin, garlic, and thyme powder and showed that these natural feed additives may be used as alternatives to an antibiotic growth promoter in broiler production (Raphaël et al., 2017). These results were supported by another study conducted by El-Faham et al. (2014), that concluded that use of natural additives in broiler diet tends to improve the performance of broiler chickens. Moreover, there is no negative impact of using these natural additives on the broilers (El-Faham et al., 2014).

\section{Conclusion}

Use of herbal natural feed additives in form of ginger root powder and apple cider vinegar were not successful in enhancing the production of broiler chcikens. The study results have clearly shown a negative impact of the natural additive supplements on growth of broiler chickens. The study has provided adequate information about ginger powder as a dietary additive and its effect on production parameters, meat quality and metabolic parameters; however, the information about the effect of apple cider vinegar is not welldocumented. Future studies may be needed to validate the present findings related to apple cider vinegar as a dietary additive.

\section{Acknowledgements}

The author is very thankful to The Jordan University for financial support and to all the associated personnel in any reference that contributed in/for the purpose of this research.

\section{Conflict of Interest Declaration}

The author declares no conflict of interest.

\section{References}

Ademola, S.G., Farinu, G.O. \& Babatunde, G.M., 2009. Serum lipid,growth and haematological parameters of broilers fed garlic, ginger and their mixtures. World J. Agric. Sci, 5, 99-104.

Ademola, S.G., Farinu, G.O. \& Babatunde, G.M., 2009. Serum lipid, growth and haematological parameters of broilers fed garlic, ginger and their mixtures. World J. Agric. Sci. 5, 99-104. Doi: 10.4314/bja.v4i1.41934

Aletor, V. A., Hamid, I. I., Niess, E. \& Pfeffer, E., 2000. Low - protein amino acid - supplemented diets in broiler chickens: effects on performance, carcass characteristics, whole - body composition and efficiencies of nutrient utilisation. Journal of the Science of Food and Agriculture, 80, 547-554.

Bordia, A.M.K.H., 1981. Effect of garlic on blood lipids in patients with coronary heart disease. The American journal of clinical nutrition. 34, 2100-2103. Doi: 10.1016/s0952-3278(98)90034-5

Budak, N.H., Aykin, E., Seydim, A.C., Greene, A.K. \& Guzel - Seydim, Z.B., 2014. Functional properties of vinegar. Journal of food science. 79. Doi: 10.1111/1750-3841.12434

Choi, I.H., Park, W.Y. \& Kim, Y.J., 2010. Effects of dietary garlic powder and a-tocopherol supplementation on performance, serum cholesterol levels, and meat quality of chicken. Poultry Science. 89, 1724-1731. Doi: 10.3382/ps.2009-00052

Costa, L.B., Tse, M.L.P. \& Miyada, V.S., 2007. Extratos vegetais como alternativas aos antimicrobianos promotores de crescimento para leitões recém-desmamados. Revista Brasileira de Zootecnia. 36, 589-595. Doi: 10.1590/s151635982007000300011 
Cross, D.E., McDevitt, R.M., Hillman, K. \& Acamovic, T., 2007. The effect of herbs and their associated essential oils on performance, dietary digestibility and gut microflora in chickens from 7 to 28 days of age. British poultry science. 48, 496-506. Doi: 10.1080/00071660701463221

Deeb, N. \& Cahaner, A., 2001. Genotype-by-environment interaction with broiler genotypes differing in growth rate. 1. The effects of high ambient temperature and naked-neck genotype on lines differing in genetic background. Poultry Science, 80, 695-702.

Demir, E., Sarica, S., Ozcan, M.A. \& Suicmez, M., 2005. The use of natural feed additives as alternatives to an antibiotic growth promoter in broiler diets. Archiv fur Geflugelkunde. 69, 110-116. Doi: 10.1080/00071660301944

Elagib, H. A., Abbas, S. A. \& Elamin, K. M., 2013. Effect of different natural feed additives compared to antibiotic on performance of broiler chicks under high temperature. Bull. Env. Pharmacol. Life Sci, 2, 139-144.

Elagib, H.A., El-Amin, W.I.A. \& Malik, H.E.E., 2015. Effect of dietary garlic (Allium sativum) supplementation as feed additive on broiler performance and blood profile. Doi: 10.5455/jasa.20130219104029

Elamin, K.M., Elagib, H.A. \& Abbas, S.A., 2015. Effect of Different Natural Feed additives compared to Antibiotic on performance of Broiler chicks Under high Temperature.

El-Faham, A. I., Ali, N. G. \& El-Maaty, H. M., 2014. Effect of using some natural feed additives to substitute antibiotic growth promoters on performance and blood parameters of broilers. Egypt Poultry Science, 34, 735-750.

Fakhim, R., Ebrahimnezhad, Y., Seyedabadi, H.R. \& Vahdatpour, T., 2013. Effect of different concentrations of aqueous extract of ginger (Zingiber officinale) on performance and carcass characteristics of male broiler chickens in wheat-soybean meal based diets. Journal of Bioscience and Biotechnology. 2, 95-99.

Ferrini, G., Baucells, M.D., Esteve-Garcia, E., \& Barroeta, A.C., 2008. Dietary polyunsaturated fat reduces skin fat as well as abdominal fat in broiler chickens. Poultry Science. 87, 528-535. Doi: 10.3382/ps.2007-00234

Gebert, S., Bee, G., Pfirter, H.P. \& Wenk, C. 1999. Phytase and vitamin E in the feed of growing pigs: 1. Influence on growth, mineral digestibility and fatty acids in digesta. Journal of Animal Physiology and Animal Nutrition. 81, 9-19. Doi: 10.1046/j.1439-0396.1999.811187.x

Gilani, S.M.H., Zehra, S., Galani, S. \& Ashraf, A., 2018. Effect of natural growth promoters on immunity, and biochemical and haematological parameters of broiler chickens. Tropical Journal of Pharmaceutical Research. 17, 627-633. Doi: 10.4314/tjpr.v17i4.9

Jeacocke, R.E., 1977. Continuous measurements of the $\mathrm{pH}$ of beef muscle in intact beef carcases. International Journal of Food Science \& Technology. 12, 375-386.Doi: 10.1111/j.1365-2621.1977.tb00120.x

Karangiya, V.K., Savsani, H.H., Patil, S.S., Garg, D.D., Murthy, K.S., Ribadiya, N.K. \& Vekariya, S.J., 2016. Effect of dietary supplementation of garlic, ginger and their combination on feed intake, growth performance and economics in commercial broilers. Veterinary world. 9, 245.

Kim, S.W., Fan, M.Z. \& Applegate, T.J., 2008. Nonruminant nutrition symposium on natural phytobiotics for health of young animals and poultry: mechanisms and application. Journal of animal science. 86, E138-E139. Doi: 10.2527/jas.2007-0769

Kim, Y.J., Jin, S.K. \& Yang, H.S., 2009. Effect of dietary garlic bulb and husk on the physicochemical properties of chicken meat. Poultry Science. 88, 398-405. Doi: 10.3382/ps.2008-00179

Konjufca, V.H., Pesti, G.M. \& Bakalli, R.I., 1997. Modulation of cholesterol levels in broiler meat by dietary garlic and copper. Poultry science. 76, 1264-1271. Doi: 10.1093/ps/76.9.1264

Nascimento, M.S., Silva, N., Catanozi, M.P.L.M. \& Silva, K.C., 2003. Effects of different disinfection treatments on the natural microbiota of lettuce. Journal of food protection. 66, 1697-1700. Doi: 10.4315/0362-028x-66.9.1697

Naveena, B.M., \& Mendiratta, S.K., 2001. Tenderisation of spent hen meat using ginger extract. British poultry science. 42, 344-349. Doi: 10.1080/00071660120055313

Papatsiros, V.G., Christodoulopoulos, G. \& Filippopoulos, L.C., 2012. The use of organic acids in monogastric animals (swine and rabbits). Journal of Cell and Animal Biology. 6, 154-159.

Ramiah, S.K., Zulkifli, I., Rahim, N.A.A., Ebrahimi, M. \& Meng, G.Y., 2014. Effects of two herbal extracts and virginiamycin supplementation on growth performance, intestinal microflora population and fatty acid composition in broiler chickens. Asian-Australasian journal of animal sciences. 27, 375.

Raphaël, K. J., Hervé, M. K., Ruben, N. T., Francklin, T., Ronald, K., Antoine, Y. \& Alexis, T., 2017. Effect of dietary mimosa small bell (Dichostachys glomerata) fruit supplement as alternative to antibiotic growth promoter for broiler chicken. Journal of World's Poultry Research, 7, 27-34.

Riaz, H., Begum, A., Raza, S.A., Khan, Z.M.U.D., Yousaf, H. \& Tariq, A., 2015. Antimicrobial property and phytochemical study of ginger found in local area of Punjab, Pakistan. International Current Pharmaceutical Journal. 4, 405-409. Doi: 10.3329/icpj.v4i7.23591

Sams, A.R. \& Janky, D.M., 1986. The influence of brine chilling on tenderness of hot-boned, chill-boned, and age-boned broiler breast fillets. Poultry Science. 65, 1316-1321. Doi: 10.3382/ps.0651316

Tucker, L., 2002. Botanical broilers: Plant extracts to maintain poultry performance. Feed Int. 23, 26-29.

Zhang, G.F., Yang, Z.B., Wang, Y., Yang, W.R., Jiang, S.Z. \& Gai, G.S., 2009. Effects of ginger root (Zingiber officinale) processed to different particle sizes on growth performance, antioxidant status, and serum metabolites of broiler chickens. Poultry science. 88, 2159-2166.

Zomrawi, W.B., Atti, K.A., Dousa, B.M. \& Mahala, A.G., 2012. The effect of ginger root powder (Zingiber officinale) supplementation on broiler chicks performance, blood and serum constituents. Online J. Anim. Feed Res. 2, 457460. 